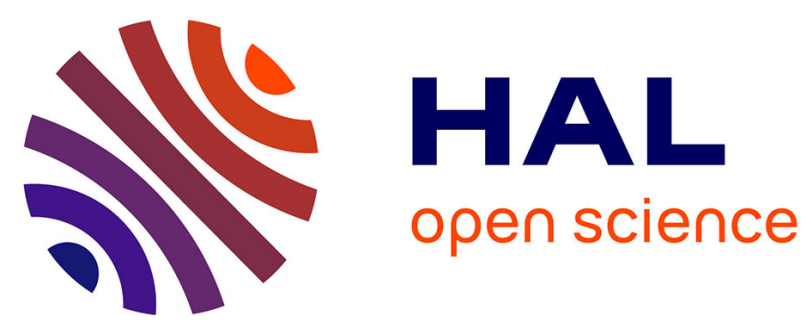

\title{
QUANTITATIVE X-RAY MICROANALYSIS OF BIOLOGICAL CRYOSECTIONS DEPENDS ON ICE CRYSTAL DAMAGE
}

\author{
K. Zierold
}

\section{> To cite this version:}

K. Zierold. QUANTITATIVE X-RAY MICROANALYSIS OF BIOLOGICAL CRYOSECTIONS DEPENDS ON ICE CRYSTAL DAMAGE. Journal de Physique Colloques, 1984, 45 (C2), pp.C2-447C2-450. 10.1051/jphyscol:19842101 . jpa-00223768

\section{HAL Id: jpa-00223768 https://hal.science/jpa-00223768}

Submitted on 1 Jan 1984

HAL is a multi-disciplinary open access archive for the deposit and dissemination of scientific research documents, whether they are published or not. The documents may come from teaching and research institutions in France or abroad, or from public or private research centers.
L'archive ouverte pluridisciplinaire HAL, est destinée au dépôt et à la diffusion de documents scientifiques de niveau recherche, publiés ou non, émanant des établissements d'enseignement et de recherche français ou étrangers, des laboratoires publics ou privés. 
JOURNAL DE PHYSIQUE

Colloque C2, supplément au $\mathrm{n}^{\circ} 2$, Tome 45, février 1984

page $\mathrm{C} 2-447$

QUANTITATIVE X-RAY MICROANALYSIS OF BIOLOGICAL CRYOSECTIONS DEPENDS ON ICE CRYSTAL DAMAGE

\author{
K. Zierold \\ Max-Planck-Institut für Systemphysiologie, RheinZanddamm 201, \\ 4600 Dortmund, F.R.G.
}

Résumé - A l'aide de la microanalyse par rayons $X$ sur des cryocoupes d'êpaisseur de $100 \mathrm{~nm}$ de standards gélatine-glycérol et de foie de rat on constate que le rapport pic sur fond ( $p / b)$ décroît avec l'augmentation de la taille des cristaux de glace.

\begin{abstract}
It is shown by X-ray microanalysis of $100 \mathrm{~nm}$ thick cryosections from glycerol-gelatine standards and rat liver that the measured peak-to-background ratio ( $p / b)$ decreases with increasing ice crystal size.
\end{abstract}

\title{
INTRODUCTION
}

X-ray microanalysis of freeze-dried cryosections is used to measure the distribution of elements in different compartments of biological cells and tissues (1-5). Ice crystal damage of the ultrastructure due to insufficient freezing velocity is a well known preparation artefact of this method ( 6 ). However, the displacement of elements, particularly of diffusible ions as sodium, chlorine, potassium and calcium, is assumed to take place in dimensions not larger than one ice crystal diameter. Therefore $X$-ray microanalysis by scanning an electron beam in an area larger than a few ice crystal diameters in size was expected to be independent on freezing damage. The experiments described in the following contradict to this assumption.

\section{MATERIALS AND METHODS}

The cooling chain preparation method as described previously $(7,8)$ is used for the preparation of the cryosections. Two kinds of specimen were studied:

1. Droplets of $20 \%$ glycerol-gelatine and $80 \%$ electrolyte solution of known composition, e.g. KCl varying in concentration between 3.1 and $200 \mathrm{mMol} / \mathrm{liter}$. These specimens were used as standards for quantitative $X_{1}$-ray microanalysis ( 9 ).

2. Freshly excised pieces of rat liver, about $1 \mathrm{~mm}$ in diameter. $100 \mathrm{~nm}$ thick cryosections, prepared by means of the Reichert FC4 cryoultramicrotome were transferred to the electron microscope under cold nitrogen gas atmosphere. Freeze-drying of the sections was enabled by evacuating the cryotransfer chamber and loosening the cold contact to the grid holder. X-ray microanalysis was performed in a Siemens Elmiskop ST $100 \mathrm{~F}$, a scanning transmission electron microscope (STEM) with a field emission gun, operated at $100 \mathrm{kV}$, by means of an energy dispersive Sili-detector (nuclear semiconductor) and a multichannel analyzer (Link Systems). The scanning area is varied from $278 \mathrm{~nm} \times 444 \mathrm{~nm}$ to $6940 \mathrm{~nm} \times 11100 \mathrm{~nm}$, analysis time was $100 \mathrm{~s}$. 
The sections were kept at $138 \mathrm{~K}$ in the electron microscope. For the evaluation of the $X$-ray peaks $p / b$-values were calculated by dividing the peak height ( $p$ ) through the mean $X-r a y$ intensity between 4.5 and 5. 5 . keV (b).

\section{RESULTS}

Fig. 1 shows a cryosection of glycerol-gelatine mixed with $200 \mathrm{mMol} / \mathrm{l}$ KCl with the mean ice crystal diameter less than $50 \mathrm{~nm}$. A corresponding X-ray spectrum is added (Fig. 2). Fig. 3 was obtained after slower freezing the same specimen type as in Fig. 1. The mean ice crystal diameter is ca. $1 / \mathrm{um}$. Fig. 4 shows the corresponding $X-r a y$ spectrum. $p / b-v a l u e s$ for sulfur and potassium, derived from $x$-ray spectra of cryosections of glycerol-gelatine mixed with KCl are sketched in Fig. 5 and 6 , respectively. The main result is that the $p / b-v a l u e$ decreases with increasing ice crystal diameter. This holds for diffusible ions (e.g. potassium) as well as for bound elements (e.g. sulfur). Similar results are obtained in biological specimens. Fig. 7 shows rat liver with intermediate ice crystal size. The p/b-value of phosphorus depending on the ice crystal size in the cytoplasm and the nucleus is drawn in Fig. 8 .
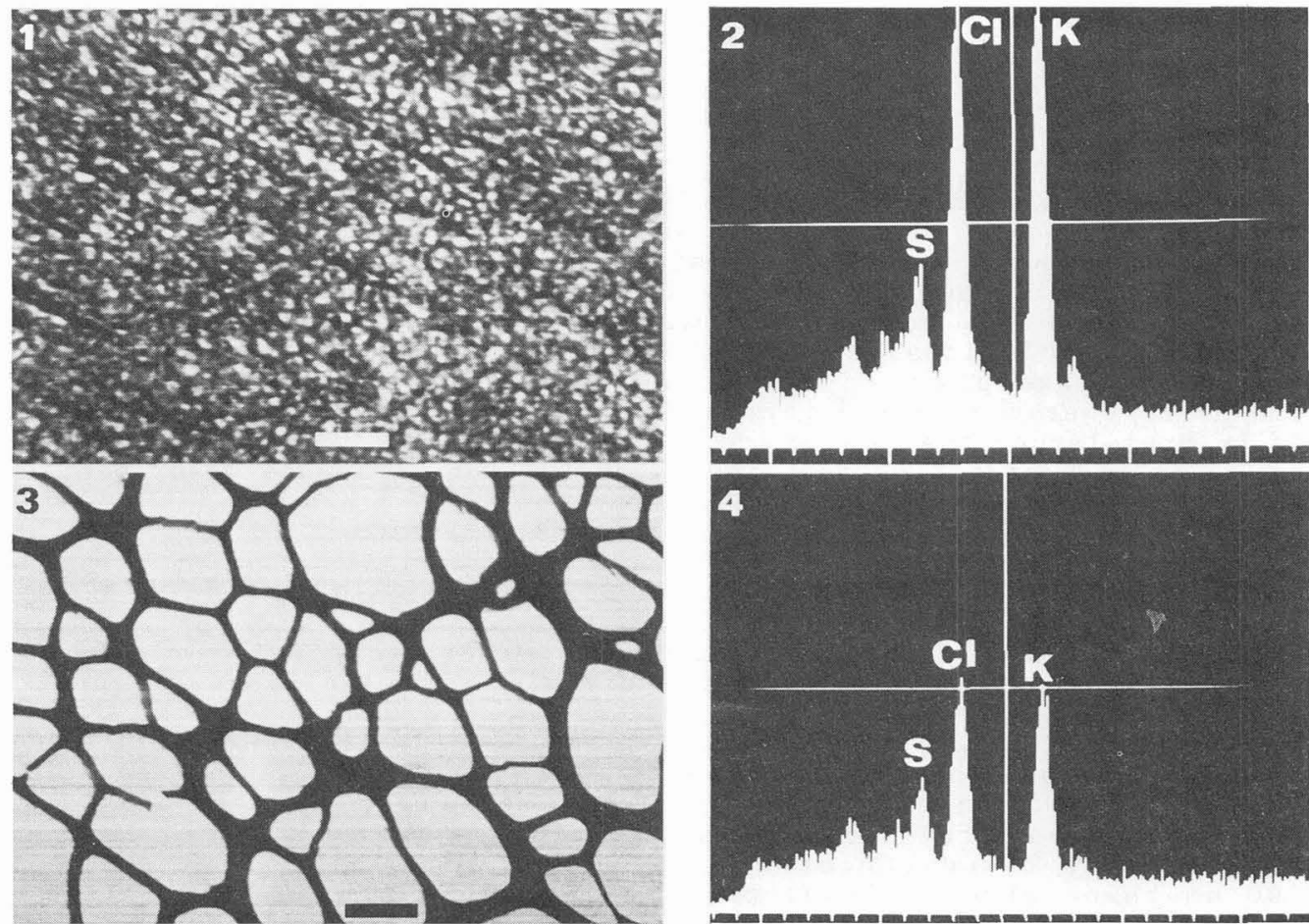

Fig. 1 - Cryosections of glycerol-gelatine mixed with $200 \mathrm{mMol} / 1 \mathrm{KCl}$, mean ice crystal size $\leq 50 \mathrm{~nm}$, bar $=250 \mathrm{~nm}$.

Fig. 2 - X-ray spectrum of the cryosection in Fig. 1. Scanning area = $694 \mathrm{~nm} \times 1110 \mathrm{~nm}$.

Fig. 3 - Cryosection of glycerol-gelatine solution mixed with $200 \mathrm{mMol} / \mathrm{KCl}$, mean ice crystal size ca. $1 / \mathrm{um}$, bar $=2.5 / \mathrm{mm}$.

Fig. 4 - X-ray spectrum of the cryosection in Fig. 3 . Scanning area = $6.94 / \mathrm{um} \times 11.1 / \mathrm{um}$. 

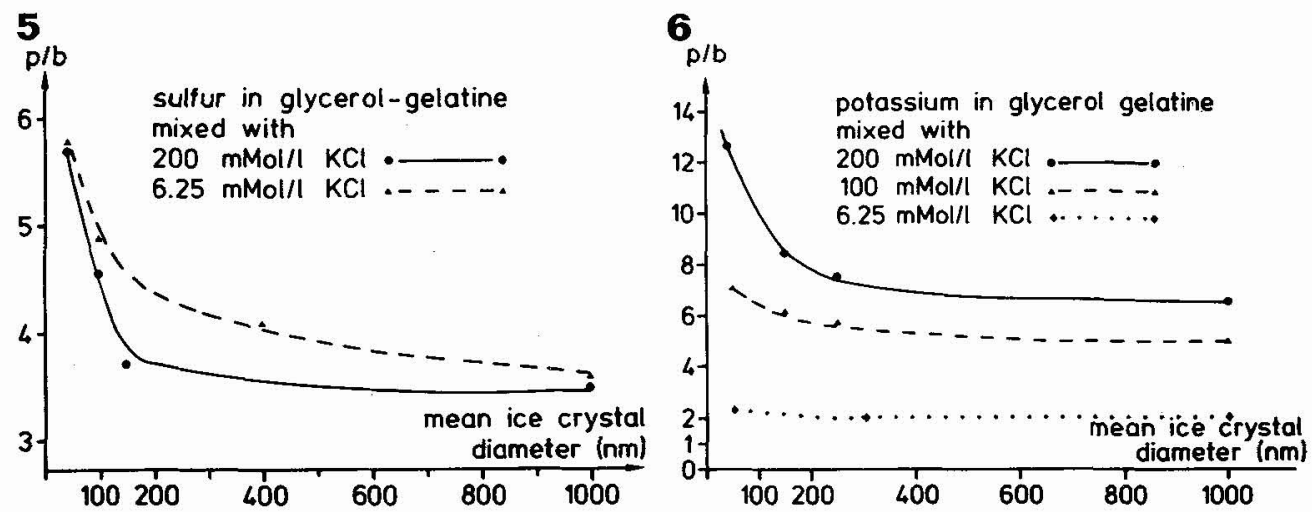

Fig. $5-p / b$ of sulfur versus mean ice crystal diameter. S.E.M. of measured points $=+8 \%$.

Fig. 6 - p/b of potassium versus mean ice crystal diameter. S.E.M. of measured points $= \pm 10 \%$.
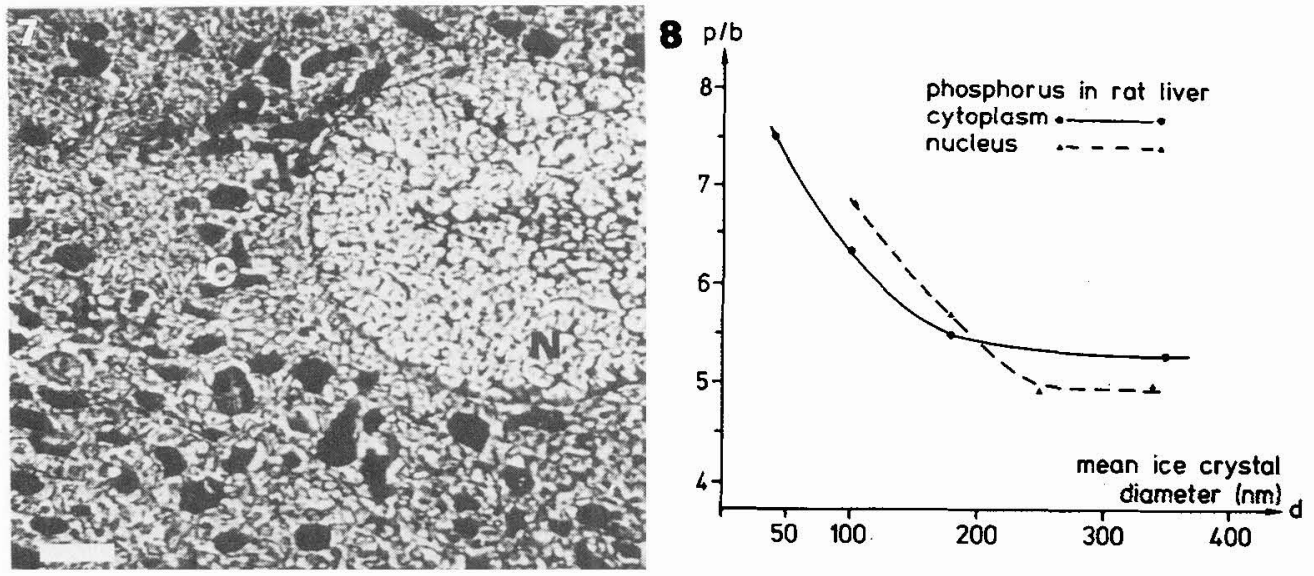

Fig. 7 - Cryosection of rat liver of intermediate ice crystal size. $C=$ cytoplasm; $N=$ nucleus; bar $=1 /$ um.

Fig. $8-p / b$ of phosphorus in the cytoplasm and nucleus of rat $I$ iver, dependent on the mean ice crystal size. S.E.M. of measured points = $\pm 10 \%$

\section{DISCUSSIDN}

These results could be explained as follows: In biological material of low density a $100 \mathrm{keV}$-electron has a mean free path of about $100 \mathrm{~nm}$. The mean distance between characteristic atoms homogeneously distributed with a volume density of $100 \mathrm{mMol} / 1=62000$ atoms in a cube of $100 \mathrm{~nm}$ length of side is about $2.5 \mathrm{~nm}$. Projected to the section surface the interatomic distance as seen from the impinging electrons is $0.4 \mathrm{~nm}$. After precipitation of ice crystals during cryofixation the density of the remaining material accumulated between the ice crystals is enhanced, and the interatomic distance between the characteristic atoms is reduced as schematically drawn in Fig. 9. Relatively small ice crystals as sketched in Fig. 9b result in small ion displacements, 
whereas larger ice crystals compress the ions in material walls of enhanced density (Fig. 9c). As a consequence electrons hitting holes left after ice sublimation penetrate the section without interaction with the specimen. Electrons hitting the material walls are scattered preferably by the atoms in the upper part of the section, and the excitation probability of the atoms below is reduced. This effect results in reduced p/b-values depending on the ice crystal size.

9

a

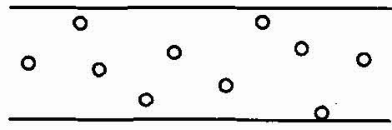

b

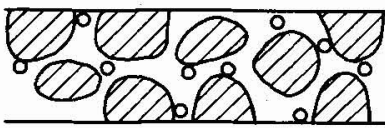

C

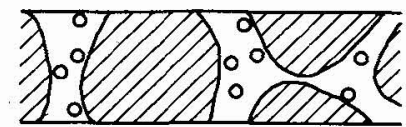

Fig. 9 - Schematic drawing of ion displacements in cryosections due to ice crystal growth as seen from the side. Circles = ions, hatched areas = ice crystals. a) The ion distribution is assumed to be statistically homogeneous in a section without ice crystals. b) Small ice crystals cause small ion displacements. The ions are still homogeneously distributed, c) Large ice crystals accumulate the ions in narrow material walls. The ion distribution becomes inhomogeneous.

\section{REFERENCES}

1. SOMLYO A.V., SHUMAN H., SOMLYO A.P., J. Cell Biol. 74 (1977) 828 .

2. DÜRGE A., RICK R., GEHRING K., THURAU K., Pflügers Arch. 373 (1978) 85.

3. HAGLER H.K., BURTON K.P., GREICO C.A., LOPEZ L.E., BUJA L.M., SCanning. Electron Microscopy 1980/III (1980) 493.

4. WENDT-GALLITELLI M.F., WOLBURG H., Scanning Electron Microscopy $1981 /$ I I (1981) 455.

5. ZIEROLD K., UItramicroscopy 10 (1982) 45.

6. PLATTNER H., BACHMANN L., Int. Rev. Cytol. 79 (1982) 237.

7. ZIEROLD K., J. Microsc. 125 (1982) 149.

8. ZIEROLD K., Scanning Electron Microscopy 1982/III (1982) 1205.

9. ROOMANS G., SEVEUS L.A., J. Submicr. Cytol. $\underline{9(1)}(1977) 31$. 